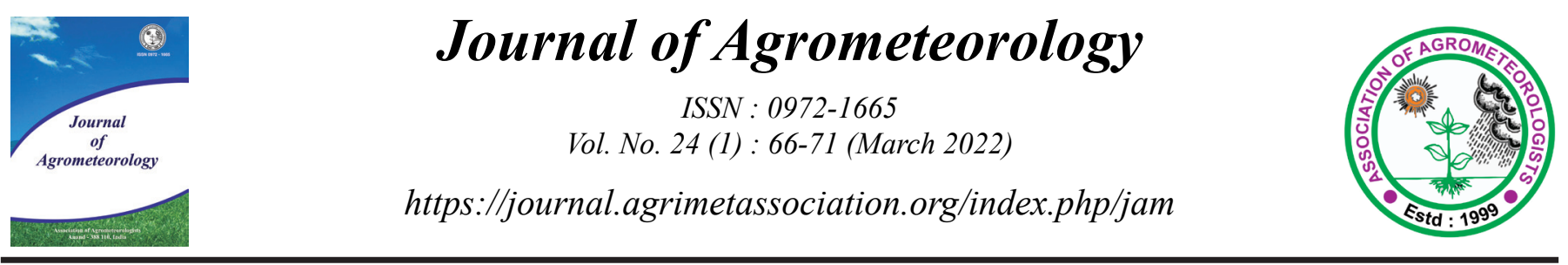

Research Paper

\title{
Effect of meteorological parameters on Karnal bunt incidence in wheat under different agroclimatic zones of Punjab
}

\author{
SARABJOT KAUR SANDHU ${ }^{*}$, ANURAG ATTRI ${ }^{1}$ and RITU BALA ${ }^{2}$ \\ ${ }^{1}$ Dept of Climate Change \& Agricultural Meteorology, PAU, Ludhiana, India \\ ${ }^{2}$ Dept of Plant Breeding and Genetics, PAU, Ludhiana, India \\ "Corresponding author email : skchahal@pau.edu
}

\begin{abstract}
To quantify the effect of meteorological parameters on incidence of Karnal bunt in wheat crop, an investigation was done using 9 to 12 season's data of Bathinda and Ludhiana stations of Punjab. Maximum temperature during March in range of $25-31^{\circ} \mathrm{C}$, minimum temperature of February $\left(8.5-11.0^{\circ} \mathrm{C}\right)$, morning and evening relative humidity of March in range of 85-95 and 40-60 per cent respectively, rainfall more than $25 \mathrm{~mm}$ with sunshine hours 5.5-9.0 hrs/day during mid-February to mid-March favour Karnal bunt in wheat crop. Maximum temperature of March showed significant negative correlation with incidence of Karnal bunt whereas minimum temperature of February showed significant positive correlation with disease incidence at both locations. Morning and evening relative humidity showed significant positive correlation with disease incidence. Rain amount and rainy days during mid-February to mid-March significantly influenced disease incidence. Sunshine hours had negative correlation with disease incidence. Backward multiple linear regression (BMLR) analysis indicated maximum temperature, rainfall and sunshine hours play significant role in Karnal bunt incidence at Ludhiana. However, at Bathinda, maximum temperature, evening time relative humidity, rain amount and rainy days played significant role.
\end{abstract}

Key words: Karnal bunt, wheat, critical ranges, backward multiple linear regression

Wheat is the second most important cereal crop of India after rice and also a major crop during rabi season in north western states like Punjab, Haryana etc. In Punjab, during 2019-20, it was grown on 35.20 lakh hectares with production of 176.20 lac tonnes with grain yield of $50.04 \mathrm{q} /$ ha (Anon., 2021). Wheat is the cool season crop, high temperature at the time of sowing as well as during reproductive stage leads to poor tillering, early heading and reduction in grain weight, respectively which ultimately reduces its yield. Life cycle of plant depend upon on the weather conditions during cropping season. Similarly, activity of the pathogens depends upon the meteorological parameters. Karnal bunt is becoming a major disease of wheat from minor one, especially in northwestern India. Karnal bunt caused by fungus Tilletia indica, was first reported by Mitra at Karnal in 1931. It is also known as new bunt or partial bunt. Flowering stage of wheat is vulnerable to attack by Tilletia indica and when the grains have developed, the disease become apparent. Wheat grain is incompletely or wholly converted into black powdery masses enclosed by the pericarp. It does not affect all the ear heads of the plant and not all grains are bunted in an ear. Only under severe cases embryo of the seed gets infected and endosperm remain uninfected (Mansoori, 2015). Karnal bunt of wheat is seed, soil and air borne disease, but it is not systemic in nature. When the host is at the flowering stage, the soil and seed borne teliospores germinates. They germinate from mid-February to mid-March, when suitable soil moisture and temperature are available. At flowering time, high humidity and low temperature lead to conditions conducive to infection. Initially it was a minor disease but became epidemic in 1976, 1979, 1981-83 and 1986 (Bala and Kaur, 2020). The variation in disease development was due to varietal susceptibility and environment conditions (Sharma et al.,2004). In Punjab, the disease reported to be rigorous, when temperature from February onward was $18^{\circ} \mathrm{C}$ to $22^{\circ} \mathrm{C}$ with above 70 per cent relative humidity. The moisture on the soil surface, for teliospore germination as well as for infection on the spike by secondary sporidia, is the most important factor (Rai, 2009). Weather parameters viz. rainfall, maximum temperature, evening relative humidity, sunshine hours and number of rainy days are important for outbreak and spread of the disease (Singh et al., 2010). In the present era of climate change and variability, Karnal bunt is a disease with a high potential of re-emergence in the areas where

Article info - DOI: https://doi.org/10.54386/jam.v24i1.781

Received: 8 September 2021; Accepted: 29 December 2021; Published online: 11 February 2022

This work is licenced under a Creative Common Attribution 4.0 International licence@Author(s),Publishing right@ Association of Agrometeorologists 
it is already endemic as well as its diffusion to new areas (Bishnoi et al., 2020). So keeping in view the importance of meteorological parameters in development of incidence of Karnal bunt, an analysis was conducted using long term data and critical ranges of various meteorological parameters conducive for Karnal bunt incidence in Ludhiana and Bathinda districts of Punjab.

\section{MATERIALS AND METHODS}

\section{Karnal bunt incidence data}

The data of Karnal bunt incidence of 12 seasons i.e. from 2009-10 to 2020-21 of Ludhiana district and of 9 seasons i.e. from 2010-11 to 2018-19 of Bathinda district were obtained from the Wheat Section, Department of Plant Breeding and Genetics, PAU, Ludhiana. The wheat grain samples were collected from the various grain markets in both the districts. Every year grain markets were surveyed and 15-30 samples were taken from each grain market. Samples of $500 \mathrm{~g}$ to $1000 \mathrm{~g}$ of grains from different heaps of wheat were collected randomly in paper bags. And the Karnal bunt incidence was calculated by using following formula:

$$
\text { Disease incidence }(\%)=\frac{\text { No. of infected grains }}{\text { Total no. of grains examined }} \times 100
$$

\section{Meteorological data}

The meteorological data of the respective districts were obtained from Department of Climate Change and Agricultural Meteorology, PAU, Ludhiana. The meteorological data of different parameters were used for three critical time periods viz., February (I period), 15 Feb-15 March (II period) and March (III period) because during this period wheat is at anthesis and ear formation stages which are most vulnerable stages to Karnal bunt development under Punjab environmental conditions.

\section{Statistical analysis}

Correlation coefficients were calculated between data of Karnal bunt disease incidence and different meteorological parameters viz., temperature, relative humidity, sunshine hours (for Ludhiana), rain amount and rainy days occurred during different critical periods assigned. For the analysis of disease data, the multiple linear regression (MLR) technique happens to be most flexible where disease incidence is being taken as dependent variable (Y) and different meteorological parameters as independent variables. This statistical technique uses several explanatory variables to predict the outcome of a response variable i.e. dependent variable. The generalized formula for MLR is as follows:

\section{$\mathrm{Y}=\beta 0+\beta 1 \mathrm{xi} 1+\beta 2 \mathrm{xi} 2+\ldots+\beta p \mathrm{xin}+\epsilon$}

Wh ere, $i=n$ obs erva tion $\mathrm{s} ; \mathrm{Y}=$ depe nden $\mathrm{t}$ variable; $\beta 0=$ intercept (constant term); $x i=$ exp lanatory variables; $\beta p=$ slope coefficients fo $r$ ea ch e xpla nato ry v ariable; $\epsilon=$ the model's error term (also known as the residuals)

Multiple linear regression equations were developed us ing most fav oura ble me teorological parameters during different critical periods. It can be observed from MLR technique that number of parameters have been taken as independent va riables to predict the dependent variable. But, because of colinearity between these independent variables because of the results ma y not be significant. To determine multi-colinearity among va riables, variance inflation factors (VIF) for each independent variable using statistical analysis software R (ver. 4.1.1, car library) was calculated. To remove the non-impressive parameters step by step, backward multiple linear regression (BMLR) method based on Akaike Information Criterion (AIC) was applied to get the best fit model. The model with the minimum value of the AIC is often the best model for prediction. The last equation developed from this analysis has parsimonious parameters with acceptable accuracy. Th is BMLR analysis was conducted using statistical analysis software R (ver. 4.1.1, MASS package).

\section{RESULTS AND DISCUSSION}

\section{Karnal bunt incidence}

The respective disease incidence data of Karnal bunt in Ludhiana and Bathinda districts have been presented in Table 1. Maximum infected samples $(98.4 \%)$ were recorded in the crop se ason of 2014-15 and minimum (1.59\%) in the crop season of 2016-17 at Ludhiana. The maximum infected samples in Bathinda di strict were recorded in crop season of 2010-11 and minimum in the crop season of 2016-17. During year 2010-11, 92 per cent infected samples were recorded, whereas during 2016-17 only 6.05 per cent collected samples were infected. Weather conditions played an important role in year to year variations in infected samples and average disease infection. Bala et al., (2013) too concluded that in Punjab, year to year variations have occurred in the incidence of Karnal Bunt. A total of 10593 grain samples collected during 20052012 and of 3677 (34.71\%) samples were infected with Karnal bunt disease.

\section{Correlation analysis}

The correlation coefficients between the meteorological parameters and incidence of Karnal bunt were worked out and have be en presented in Table 2 for Ludhiana and Bathinda. The data of weather parameters was included for three critical periods viz. period I i.e, February month weather data and period II i.e. weather parameters for mid-February to mid-March period and period III i.e March month. Correlation analysis for Ludhiana indicated that in case of first critical period, minimum temperature, evening relative humidity and sunshine hours showed significant correlation whereas ma ximum temperature, morning relative humidity and rainfall we re not significantly correlated. During second critical period, evening relative humidity, rainfall, rainy days and sunshine hours showed significant correlation with disease incidence. During third critical period maximum temperature, morning and evening relative humidity, rainfall and rainy days showed significant correlation. In co rroboration with this study, Kaur (2001) also reported positive co rrelation between morning relative humidity and teliospores germination and maximum teliospores germinated at mean relative hu midity of more than 75 per cent. For Bathinda, minimum te mperature along with morning and evening relative humidity significantly influenced disease incidence. Maximum temperature, re lative humidity and rainfall were significantly correlated with Karnal bunt incidence. Morning relative humidity of March showed 
Table 1: Karnal bunt incidence (\%) at Ludhiana and Bathinda districts of Punjab

\begin{tabular}{|c|c|c|}
\hline Year & Ludhiana & Bathinda \\
\hline 2009-10 & 10.00 & -- \\
\hline 2010-11 & 30.30 & 92.00 \\
\hline 2011-12 & 3.36 & 6.40 \\
\hline $2012-13$ & 35.96 & 8.24 \\
\hline 2013-14 & 39.56 & 8.24 \\
\hline 2014-15 & 98.40 & 87.50 \\
\hline $2015-16$ & 23.64 & 19.53 \\
\hline 2016-17 & 1.59 & 6.05 \\
\hline $2017-18$ & 28.57 & 17.58 \\
\hline 2018-19 & 33.24 & 32.37 \\
\hline $2019-20$ & 54.00 & -- \\
\hline $2020-21$ & 30.00 & -- \\
\hline
\end{tabular}

higher r-value. Mavi et al., (1992) also reported that evening relative humidity during $9^{\text {th }}$ to $11^{\text {th }}$ standard meteorological week had positive correlation with disease intensity. Kaur et al., (2007) also developed the correlation coefficients of weather parameters with Karnal bunt incidence in Punjab and found that maximum temperature and morning relative humidity had non-significant correlation whereas minimum temperature had significant positive correlation.

\section{Meteorological parameters and disease incidence}

Quantification of most favourable meteorological parameters on the basis of correlation analysis for incidence of Karnal bunt was done to identify the critical values of different meteorological parameters has been presented in Table 3. From first critical period i.e. in February month, minimum temperature in the range of $8.5-11^{\circ} \mathrm{C}$ was most vulnerable for disease incidence. Maximum temperature, morning and evening relative humidity

Table 2 : Correlation coefficient between Karnal bunt incidence and different weather parameters

\begin{tabular}{|c|c|c|c|c|c|c|c|c|c|c|c|c|c|}
\hline \multirow{2}{*}{$\begin{array}{c}\text { Period/ } \\
\text { Parameters }\end{array}$} & \multicolumn{2}{|c|}{$\operatorname{Tmax}\left({ }^{\circ} \mathrm{C}\right)$} & \multicolumn{2}{|c|}{$\operatorname{Tmin}\left({ }^{\circ} \mathrm{C}\right)$} & \multicolumn{2}{|c|}{ RHm (\%) } & \multicolumn{2}{|c|}{$\mathrm{RHe}(\%)$} & \multicolumn{2}{|c|}{$\mathrm{RF}(\mathrm{mm})$} & \multicolumn{2}{|c|}{ RD (No.) } & \multirow{2}{*}{$\begin{array}{l}\text { BSS (hr/day) } \\
\text { LDH }\end{array}$} \\
\hline & LDH & BTH & $\mathrm{LDH}$ & BTH & LDH & BTH & LDH & BTH & $\mathrm{LDH}$ & BTH & LDH & BTH & \\
\hline February (I-period) & -0.03 & 0.04 & $0.63 *$ & $0.57 *$ & 0.23 & $0.64 *$ & $0.63 *$ & $0.55^{*}$ & 0.34 & 0.30 & 0.45 & 0.17 & $-0.55^{*}$ \\
\hline March (III-period) & $-0.49 *$ & -0.33 & 0.07 & -0.01 & $0.50 *$ & $0.67 *$ & $0.84 * *$ & $0.45^{*}$ & $0.70^{*}$ & 0.46 & $0.72 *$ & 0.30 & -0.44 \\
\hline
\end{tabular}

LDH- Ludhiana, BTD - Bathinda;

Tmax - Max Temp; Tmin - Min Temp; RHm - Morning RH; RHe- Evening RH; RF - Rainfall; RD - Rainy Day; BSS-Bright Sun Shine *Significant at $5 \%$ level of significance, $* *$ significant at $1 \%$ level of significance

\#Bold values used for development of regression models

Table 3: Critical values of different meteorological parameters favourable for incidence of Karnal bunt in wheat

\begin{tabular}{cc}
\hline Meteorological Parameter & Critical Range/ Value \\
\hline Tmax (III-period) & $25-31{ }^{\circ} \mathrm{C}$ \\
Tmin (I-period) & $8.5-11.0^{\circ} \mathrm{C}$ \\
RHm (III-period) & $85-95 \%$ \\
RHe (III-period) & $40-60 \%$ \\
RF (II-period) & $>25 \mathrm{~mm}$ \\
RD (II-period) & $>3$ days \\
SSH (II-period) & $5.5-9.0 \mathrm{hrs} /$ day \\
\hline
\end{tabular}

during March period in the range of $25-31^{\circ} \mathrm{C}, 85-95$ and $40-60$ per cent respectively, were most favourable for disease incidence at both the locations. Rainfall $(>25 \mathrm{~mm})$ and rainy days ( $>3.0)$ during mid-February-mid March period were most favourable for disease incidence. For Ludhiana, sunshine hours during mid-February-mid March period in the range of 5.5-9.0 hrs/day were congenial. Biswas et al., (2013) also concluded that Karnal bunt of wheat was influenced by meteorological parameters. Day temperature values between 25 $30^{\circ} \mathrm{C}$ and night time temperature values between $10-15^{\circ} \mathrm{C}$ showed higher probability density asserting good association with sporidial showering. However, individually, relative humidity at morning or evening time did not show such association. Though, the diurnal range of RH was important as RHm $>90$ per cent and RHe between 40 and 60 per cent gave the maximum combined probability density
Table 4: Variance inflation factors (VIF) of individual predictive variables

\begin{tabular}{lcc}
\hline \multicolumn{1}{c}{ Parameters } & Ludhiana & Bathinda \\
\hline Tmax & 8.50 & 1.41 \\
Tmin & 5.43 & 1.88 \\
RHm & 4.54 & 4.81 \\
RHe & 9.22 & 5.00 \\
Rainfall (RF) & 24.9 & 18.70 \\
Rainy days (RD) & 27.9 & 5.89 \\
Sunshine hours (SSH) & 11.6 & NA \\
\hline
\end{tabular}

with daily sporidial showering. Further to make out distribution of different meteorological parameters during incidence and development of disease box plots were plotted using pooled data at both locations and has been depicted in Fig.1. These plots helped to recognize significant meteorological parameters in quantitative terms. The temperature around $27^{\circ} \mathrm{C}(\max )$ and $9.5^{\circ} \mathrm{C}(\min )$ were found to be deciding factor for the development of Karnal bunt after its establishment in the crop field. Higher RHm (>89\%) as well as $\mathrm{RHe}(>45 \%)$ during most of the season facilitate the development of Karnal bunt. Rainfall around $38 \mathrm{~mm}$ along with 3 rainy days favoured disease incidence. Sunshine hours of nearly $7.5 \mathrm{hrs} /$ day during the season favoured disease incidence at Ludhiana. Chahal (2001) reported too, that environmental factors played major role in occurrence of disease in epidemic form. Moderate temperature 

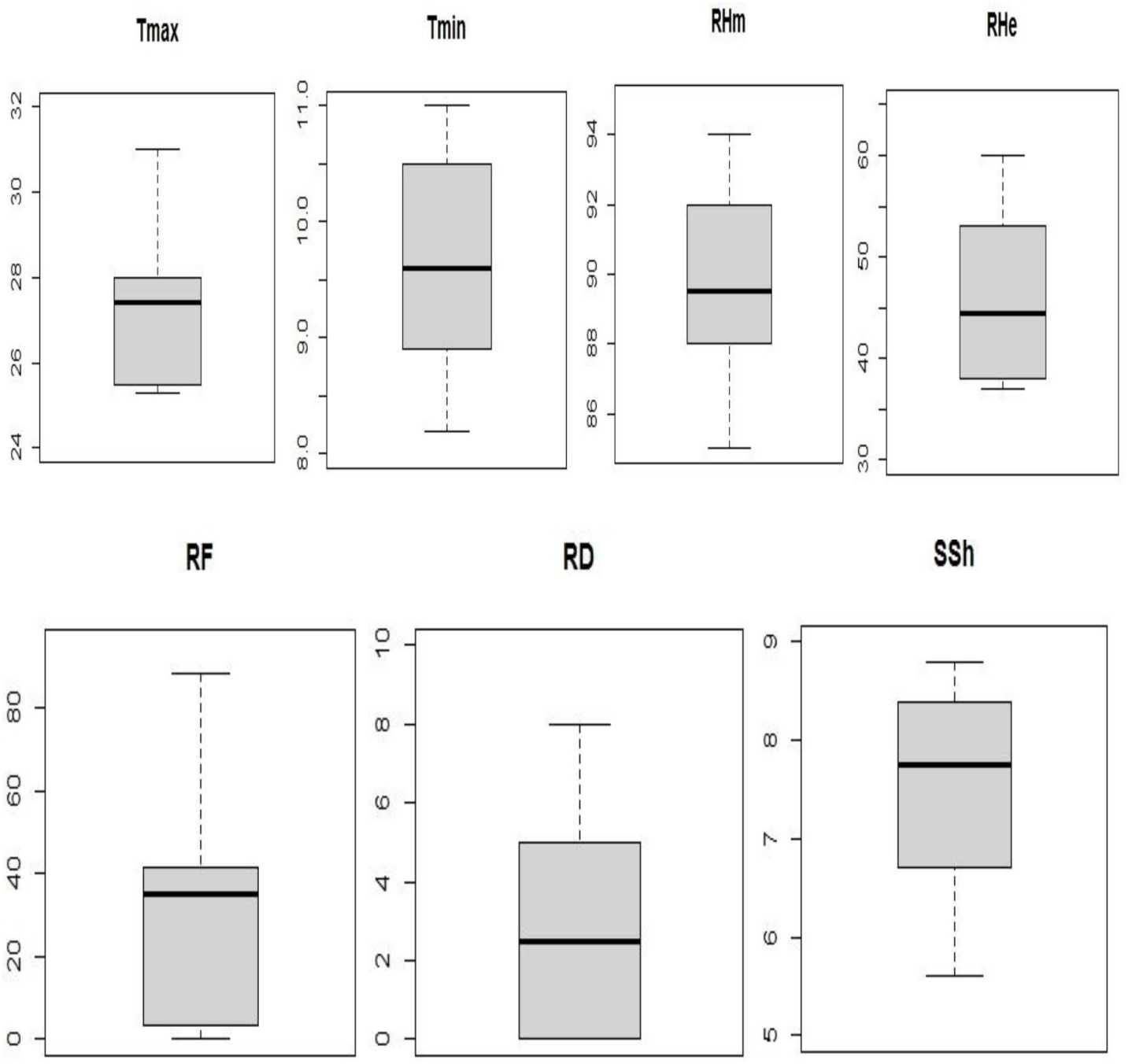

Fig.1: Distribution of different meteorological parameters during Karnal bunt incidence years

between $19-20^{\circ} \mathrm{C}, \mathrm{RH}>70$ per cent, cloudiness and light rains during anthesis favored the development of Karnal bunt. With day time temp of $22 \pm 2^{\circ} \mathrm{C}, \mathrm{RHe}>48$ per cent, partly cloudy (3.5 hour per day cloudiness) and $>3$ rainy day in last week of February and first week of March at boot to spike emergence stage, outbreak of Karnal bunt supposed to occur. Number of rainy days at boot leaf stage found to be more important for disease development. Khan et al., (2010) also concluded that if the average minimum temperature range between 11 to $16^{\circ} \mathrm{C}$ and maximum temperature 27.5 to $31.1^{\circ} \mathrm{C}$ in month of February and March in Pakistan, then the incidence chances of Karnal bunt will be more. They further reported that high rainfall of $1.1 \mathrm{~mm}$, relative humidity of 49 per cent, low minimum temperature of $14.8^{\circ} \mathrm{C}$ and low maximum temperature of $27.8^{\circ} \mathrm{C}$ during the year 2007 caused more disease incidence when compared with season of 2006. Jakhar et al.,(2019) also reported that reason behind the high occurrence of Karnal bunt in Karnal was due to favorable temperature, high $\mathrm{RH}$, cloudy and wet weather.

Variance inflation factors (VIF) of seven predictive variables concluded several variables that were highly intercorrelated (i.e. condition of multi co-linearity). High VIF values were obtained in some meteorological parameters viz., rain amount and rainy days for Ludhiana as presented in Table 4. High VIF signified strong association among these weather variables.

\section{Development of exploratory model}

Development of exploratory model was attempted using meteorological and disease data for both the locations. Multiple linear regression (MLR) was developed using the most significant weather parameters which were perceived by correlation analysis. In MLR, disease incidence (Y) was response variable and all meteorological parameters were taken as continuous predictors. For Ludhiana, the MLR was developed by including meteorological parameters viz. minimum temperature (I-Period), rainfall, rainy days and sunshine hours from second period (mid-February to midMarch) and maximum temperature, morning and evening relative humidity from third period (March). From VIF analysis, it was evident that there was co-linearity between different independent variables so backward multiple linear regression (BMLR) analysis was done using Akaike information criterion (AIC) as presented in Table 4. The final output was a parsimonious model with lowest AIC value (57.6) using maximum temperature, rainfall and sunshine hours with significant $\mathrm{R}^{2}$ value $(0.78)$. According to the final model, 
Table 5 : BMLR based regression analysis to select appropriate exploratory model for Ludhiana and Bathinda

\begin{tabular}{lcc}
\hline I-Regression Equation at Ludhiana & AIC & $\mathbf{R}^{\mathbf{2}}$ \\
\hline $\mathrm{DI}=191.6+8.6 \mathrm{X}_{1}-5.44 \mathrm{X}_{2}-3.34 \mathrm{X}_{3}+1.87 \mathrm{X}_{4}+0.54 \mathrm{X}_{5}-0.97 \mathrm{X}_{6}-19.9 \mathrm{X}_{7}$ & 93.0 & 0.84 \\
$\mathrm{DI}=198.1+8.50 \mathrm{X}_{1}-5.21 \mathrm{X}_{2}-3.92 \mathrm{X}_{3}+2.31 \mathrm{X}_{4}+0.51 \mathrm{X}_{5}-16.91 \mathrm{X}_{7}$ & 60.6 \\
$\mathrm{DI}=142.8+5.61 \mathrm{X}_{1}-2.96 \mathrm{X}_{3}+2.03 \mathrm{X}_{4}+0.32 \mathrm{X}_{5}-13.80 \mathrm{X}_{7}$ & 59.1 & 0.84 \\
$\mathrm{DI}=-0.45+3.25 \mathrm{X}_{1}+0.98 \mathrm{X}_{4}+0.26 \mathrm{X}_{5}-14.82 \mathrm{X}_{7}$ & 58.8 & 0.84 \\
$\mathrm{DI}=73.16+3.72 \mathrm{X}_{1}+0.34 \mathrm{X}_{5}-20.66 \mathrm{X}_{7}$ & 57.6 & 0.78 \\
$\mathrm{II}-$ Regression Equation at Bathinda & $\mathbf{A I C}$ & $\mathbf{\mathbf { R } ^ { 2 }}$ \\
$\mathrm{DI}=-223.2-9.41 \mathrm{X}_{1}-0.81 \mathrm{X}_{2}-3.47 \mathrm{X}_{3}+4.70 \mathrm{X}_{4}-1.06 \mathrm{X}_{5}-8.64 \mathrm{X}_{6}$ & 51.0 & 0.94 \\
$\mathrm{DI}=-215.3-9.44 \mathrm{X}_{1}+3.39 \mathrm{X}_{3}+4.55 \mathrm{X}_{4}-1.03 \mathrm{X}_{5}-8.11 \mathrm{X}_{6}$ & 49.9 & 0.94 \\
$\mathrm{DI}=85.34-9.85 \mathrm{X}_{1}+4.06 \mathrm{X}_{4}+0.50 \mathrm{X}_{5}-16.97 \mathrm{X}_{6}$ & 49.2 & 0.87 \\
\hline
\end{tabular}

Where, $\quad \mathrm{X}_{1}-\operatorname{Max} \operatorname{Temp}\left({ }^{\circ} \mathrm{C}\right) ; \quad \mathrm{X}_{2}-\operatorname{Min} \operatorname{Temp}\left({ }^{\circ} \mathrm{C}\right) ; \mathrm{X}_{3}$ - Morning RH (\%)

$\mathrm{X}_{4}$ - Evening RH (\%); $\mathrm{X}_{5}$ - Rainfall (mm); $\mathrm{X}_{6}$ - Rainy days (No.); $\mathrm{X}_{7}$ - Sunshine Hours (hr/day)

maximum temperature of March month, rainfall and sunshine hours of mid-February to mid-March period exhibited strong effect on Karnal bunt incidence at Ludhiana (Table 5). Similarly, Khan et al., (2010) conducted regression analysis between Karnal bunt incidence and various meteorological parameters and found that air temperature, rainfall, wind speed and relative humidity explained upto 84 per cent variability in disease development. The exploratory model using BMLR analysis was developed for Bathinda and predictive models has been presented in Table 5. The MLR was developed by including meteorological parameters viz. minimum temperature (I-Period), maximum temperature, evening relative humidity, rainfall and rainy days from second period (mid-Februarymid March) and morning relative humidity from third period (March). Number of meteorological parameters were omitted by the software to get the best model. The final model included maximum temperature, evening relative humidity, rainfall and rainy days with AIC value of 49.2 and these meteorological variables explained upto 87 per cent variations in disease incidence at Bathinda. Singh et al., (2018) also reported that average infection of Karnal bunt was regulated by maximum and minimum temperature, morning and evening time relative humidity, rainfall and rainy days with $\mathrm{R}^{2}$ values between 0.68 to 0.92 in different districts of Haryana state.

\section{CONCLUSION}

Among different meteorological parameters minimum temperature $\left(8.5-11.0^{\circ} \mathrm{C}\right)$ of February month, maximum temperature $\left(25-31^{\circ} \mathrm{C}\right)$ of March month, rainfall $(>25 \mathrm{~mm})$ and rainy days $(>3$ days) of mid-February-mid March period can act as key indicators for disease incidence. On the basis of developed regression models, location specific forewarning of Karnal bunt incidence can be done for timely and effective management of disease to avoid any further epidemic conditions in the region.

Conflict of Interest Statement: The author(s) declare(s) that there is no conflict of interest.

Disclaimer: The contents, opinions, and views expressed in the research article published in the Journal of Agrometeorology are the views of the authors and do not necessarily reflect the views of the organizations they belong to.
Publisher's Note: The periodical remains neutral with regard to jurisdictional claims in published maps and institutional affiliations.

\section{REFERENCES}

Anonymous (2021). Package of Practices for Crops of Punjab Rabi 2021-22, Punjab Agricultural University, Ludhiana, Pp. 101.

Bala, R. and Kaur, J. (2020). Karnal bunt A threat to export of Indian wheat. Ind.Farm., 70(09):32-34.

Bala, R., Kaur, D., Sharma, I. and Sharma, R. C. (2013) Incidence of Karnal bunt and Ear cockle in Punjab during 2005-2012. Ind. Phytopathol., 66(3): 313-315.

Biswas, B., Dhaliwal, L. K., Mann, S. K., Kaur, G. and Kashyap, P. (2013). A model based approach for predicting Karnal Bunt disease of Wheat under Punjab conditions. J.Agrometeorol.,15(2): 158-162.

Bishnoi, S.K., He, X., Phuke, R.M., Kashyap, P.L., Alakonya, A., Chhokar, V., Singh, R.P. and Singh, P.K. (2020). Karnal Bunt: A Re-Emerging Old Foe of Wheat. Front. Pl. Sci., 11:569057. doi: 10.3389/fpls.2020.569057.

Chahal, S. S. (2001). Epidemiology and management of two cereal bunts.Ind. Phytopathol.,54(2): 145-157.

Jakhar, S. S, Kumar, S. and Malik, A. K. (2019). Status of Karnal Bunt in Major Wheat Growing Regions of Northern Haryana. Curr. J. Appl. Sci. Tech., 38(2): 1-7.

Kaur, S. (2001). Dynamics of inoculums affecting occurrence of Karnal bunt epidemics in wheat. Ph.D. Dissertation, Punjab Agricultural University, Ludhiana.

Kaur, S., Hundal, S. S., Kaur, G. and Dhaliwal, L. K. (2007). Development of an epidemiological model and decision support system for the management of Karnal bunt of wheat. J. Res. Pun. Agric. Uni.,44(1): 44-49.

Khan, M. A., Shakoor, M. A., Javed, N., Arif, M. J. and Hussain, 
M. (2010). A disease predictive model for Karnal bunt of wheat based on two years environmental conditions. Pak. J.Phytopathol.,22(2): 108-112.

Mansoori, B. (2015). Biology and epidemiology of Tilletia indica inducing Karnal bunt of wheat (Triticum aestivum) in arid regions. Ind. Phytopathol.,68 (1): 39-41.

Mavi, H. S., Jhorar, O. P., Sharma, I., Singh, G., Mahi, G. S., Mathauda, S. S. and Aujila, S. S. (1992). Forecasting Karnal bunt disease of wheat-a meteorological method. Cereal. Res. Comm.,20(1): 67-74.

Rai, R. C. (2009). Status of Karnal bunt of wheat and its management. In: Proceedings of the $21^{\text {st }}$ training on Recent Advances in Plant Disease Management held from December 13, 2008 to January 02, 2009 in Uttrakhand.p.104-119.

Sharma, I., Nanda, G. S., Singh, H. and Sharma, R. C. (2004). Status of Karnal bunt disease of wheat in Punjab (19942004). Ind. Phytopathol.,54(4): 435-439.

Singh, R., Singh, R., Karwasra, S. S., Kumar A and Choudhary D (2018). Climate suitability for Karnal b u n t (Tilletia indica) disease of wheat crop in Haryana. $J$. Agrometeorol.,20: 184-187.

Singh, R., Singh, R., Singh, D., Mani, J., Karwasra, S. S. and Beniwal, M. S. (2010). Effect of weather parameters on Karnal bunt disease in wheat in Karnal region of Haryana. J. Agrometeorol., 12(1): 99-101. 